\title{
Afirmar uma Psicologia fortalecedora da Vida COM Nietzsche e Deleuze
}

http://dx.doi.org/10.1590/1984-0292/980

\author{
Fernando Hiromi Yonezawa \\ Universidade Federal do Espírito Santo, Vitória, ES, Brasil
}

Resumo

Neste estudo teórico, desejamos compreender a noção trazida por Nietzsche, de Psicologia como "morfologia da vontade de poder" e, também, investigar o problema filosófico destacado por Deleuze de liberar a vida do par ressentimento/ má-consciência. Trazemos os conceitos de vontade de poder e eterno retorno como sendo elementos de transformação do enfraquecimento que a vida sofre sob obra do ressentimento e da má-consciência. Assim, chegaremos à noção de que a Psicologia pode funcionar como estudo de uma sensibilidade das forças vitais, trabalhando em favor de fortalecer a vida, liberando-a do peso da culpa, e sem se restringir à interioridade dos sujeitos.

Palavras-chave: vida; fortalecer; Psicologia; vontade; potência.

\section{Affirming a life strengthener Psychology With Nietzsche ANd Deleuze}

\begin{abstract}
In this theoretical study we want to understand the concept brought by Nietzsche of Psychology as "morphology of the will to power" and also investigate the philosophical problem highlighted by Deleuze of releasing life peer resentment/ bad conscience. We bring the concepts of will to power and eternal recurrence as elements to transform the weakening suffered by life under the deed of resentment and bad conscience. Thus, we cum to the notion that psychology can perform as study of the vital force's sensibility, working for strengthening life, freeing it from the burden of guilt and not been limited to the subject's interiority.
\end{abstract}

Keywords: life; strenghen; Psychology; will; potency.

\footnotetext{
^Endereço para correspondência: Universidade Federal do Espírito Santo, Programa de PósGraduação em Psicologia Institucional. Av. Fernando Ferrari, 514 - sala 207, $2^{\circ}$ piso, Prédio Bárbara Weinberg. Pós-Graduação CCHN, Goiabeiras, Vitória, ES, Brasil. CEP: 29075-910. E-mail: fefoyo@yahoo.com.br
} 


\section{A questão que colocamos: tarefa vital da Psicologia}

A partir do estudo conceitual da relação entre vida e ética nas obras de Deleuze e Nietzsche, que é parte de nossa pesquisa de doutoramento em Psicologia pela Faculdade de Filosofia Ciências e Letras da Universidade de São Paulo (USP), com apoio financeiro da CAPES, passamos a compreender estes pensadores como parceiros que realizam juntos, embora em épocas diferentes, o trabalho intempestivo de tecer uma Filosofia para a vida.

Compreendemos, assim, que ambos os filósofos concebem uma Filosofia como forma de pensamento capaz de liberar a vida de qualquer princípio que pretenda fundamentá-la e dentro do qual se queira interiorizá-la. Pensamento, como diz Deleuze, não como modo de explicar ou justificar a vida, mas como Filosofia para inocentar a vida, para positivar a irresponsabilidade da vida. Deleuze $(2001$, p. 32; 35) diz ainda que desde os tempos pré-cristãos se utilizou do sofrimento para provar a injustiça da existência e, então, se ter pretexto para incutir na vida a necessidade de torná-la divina e justa em função de um juízo moral, uma explicação transcendente - Deus, a razão, a verdade, o bem. Além disso, nos lembra que se impõe aparentemente um beco sem saída ao pensamento: ou concebemos vidas demasiado loucas para se manterem vivas, ou modos de viver aplainados por uma mediocridade posta como sensatez e sabedoria. (DELEUZE, 1981, p.18) Diante deste impasse, Deleuze intervém de modo radical: elaborar um pensamento do a-fundamento.

Estas colocações deleuzeanas, sabemos, se referem a sua proposição de elaborar um modo de pensamento capaz de reverter o platonismo - enquanto fundamento moral subentendido em todo filosofar - e liberar a diferença de toda mediação, liberá-la à diferenciação. Um pensamento sem princípio, a-fundado, quer dizer: sem princípio moral, universal e transcendente, que se pretenda verdadeiro para toda forma de vida e existência, ou se queira capaz de representar as diferenciações da vida, formando uma imagem do pensamento.

Ora, um fundamento tem a motivação de eliminar pretendentes e eleger os melhores (DELEUZE, 2006b, p. 101), os verdadeiros, os justos, os corretos etc. Seu efeito imediato é o de criar uma massa de pretendentes e pretensiosos participantes, que almejam fazer parte de uma espécie de cúpula de benditos privilegiados ou associação de bem ajustados. O fundamento é uma ideia que se possui em primeiro lugar e a partir da qual se hierarquiza os pretendentes que aspiram participar do objeto de fundação (DELEUZE, 2006b, p. 101). Mas, "é o pretendente que pede o fundamento, é a pretensão que deve ser fundada" (DELEUZE, 2006b, p. 102), ou seja, somente se pode querer um fundamento na medida em que se almeja e se aspira por um princípio exterior de medida. Com efeito, o fundado e o fundante se fundam mutuamente, coemergem num só golpe. Em outros termos: o fundamento entendido como princípio anterior é uma ficção, nunca se encontra antes, mas aparece juntamente com aqueles que almejam participar de um lugar de reconhecimento. Ao invés de dar lugar à diferença em si mesma, se 
a mediatiza, subordinando-a ao fundamento (DELEUZE, 2006b, p. 106), eis a glória do pensar moral. A vida, a partir de um tal pensamento, só pode ser julgada, hierarquizada e forçada a ser justa e idêntica.

Com efeito, elaborar uma filosofia do afundamento (a-fundamento) é, nas palavras deleuzeanas, liberar as diferenças de toda mediação, a partir do momento em que o próprio fundo se vê destituído e encontra-se sempre mais um fundo sob o fundo (DELEUZE, 2006b, p. 107) ou, como diria Nietzsche, mais uma máscara sob a máscara. Notemos que estas concepções deleuzeanas parecem encontrar eco na crítica nietzschiana aos supremos valores morais e ao dogmatismo em Filosofia, o qual, se expressa na busca da verdade como mais alto trabalho. Segundo Nietzsche (1992, p. 12), a Filosofia se incumbiu de tal tarefa como se a verdade estivesse dada a ser descoberta, aguardando silenciosa no começo e fim das coisas, quando tudo isso não passou de preconcepção de um modo de valorar a vida, chamando-o verdade. O que Nietzsche questiona, afinal, não é se existe verdade, ou se uma ideia é verdadeira, mas que se tenha feito da verdade um valor fundante, sem considerar que, no fundo, se tratava de uma vontade de verdade e não apenas de uma fria, neutra e razoável posição. "Para mim, tratava-se do valor da moral" (NIETZSCHE, 2009, p. 10, grifo do autor).

Diante destas colocações a respeito da Filosofia, nos pusemos a seguinte questão, desta vez, envolvendo a Psicologia: qual seria a tarefa da Psicologia, se colocada diante da vida? Não seria esta também a tarefa de uma Psicologia vitalista? Liberar a vida dos pesos forjados dos fundamentos, da culpa e do erro, não seria a serviço disso que poderia estar a Psicologia? Parece-nos haver aí uma zona de indiscernibilidade, um ponto de encontro entre Filosofia e Psicologia, um devir da Filosofia que, no seu filosofar, se colocaria num caminho de investigação da Psicologia. Ora, para Nietzsche (1992, p. 29) a Psicologia, exatamente como a Filosofia, esteve até hoje presa a temores morais; ela também teria se aventurado somente de maneira discreta e bem comportada no caminho de conhecer os afetos.

Entretanto, Nietzsche (1992, p. 29, grifo do autor) define, de maneira muito provocadora, a Psicologia como sendo "morfologia e teoria da evolução da vontade de poder", sendo que "a vontade de poder é a forma de afeto primitiva, todos os outros afetos são apenas configurações suas" (NIETZSCHE, 2008, p. 348, grifo do autor). Mais adiante entenderemos melhor esta definição nietzschiana de Psicologia. Por hora, diante do fato de que tanto a Psicologia quanto a Filosofia parecem, sofrer de males comuns, talvez possamos dizer que podem se confundir a tarefa de uma Filosofia para a vida e de uma Psicologia vital. Sabemos bem que Deleuze e Guattari colocam como tarefa própria do filosofar a atividade de criação de conceitos; porém, nosso intuito aqui é o de, a partir de Nietzsche e Deleuze, realizar o exercício criativo - portanto, exercício livre e nobre, diria Nietzsche - de pensar uma Psicologia em conexão com a vida. De que modo, afinal, os conceitos filosóficos de Deleuze e Nietzsche poderiam nos ajudar a compor uma das faces de uma Psicologia vitalista? Sem pretender fundar uma nova Psicologia, ou firmar um tipo de verdade final, esta é também uma de nossas questões neste trabalho. 
Então, partindo destas colocações de Deleuze e Nietzsche, nossa intenção será a de selecionarmos uma composição conceitual que contribua tanto para a produção desta noção de uma Psicologia capaz de inocentar e liberar a vida, como para compreender esta definição nietzscheana de Psicologia. Não nos importa tratar das especificidades disciplinares da Psicologia e da Filosofia, mas tomar de roubo conceitos dos pensamentos destes autores que possam trazer elementos para compor a noção de uma Psicologia vitalista, que estamos propondo; além disso, é preciso considerar que a Filosofia, ao elaborar um pensamento capaz de liberar a vida, está justamente emitindo fagulhas de um modo de pensar a vida que pode ser extremamente frutífero para a Psicologia.

Assim, tampouco nos interessa discutir os objetos e objetivos da Psicologia, sua caracterização clássica ou contemporânea, já que nela, sabemos bem, há uma pluralidade realmente caótica de concepções, métodos, abordagens e focos, que de fato impedem qualquer balizamento privilegiado e generalizante para uma reflexão que ora trazemos, a não ser que tomemos por referência aquelas concepções política, social e historicamente hegemônicas - o que seria contraditório diante da concepção de um a-fundamento do pensamento.

Em função destes nossos objetivos é que nos utilizaremos da interpretação deleuzeana de Nietzsche, sem querer reduzi-lo a mero leitor nietzscheano. Como bem lembra Machado (2009, p. 29), Deleuze se utiliza do pensamento de outros filósofos com o intuito de encontrar elementos para o seu próprio pensamento, "ele fala em seu próprio nome usando o nome de outro". Entendemos que Deleuze fala dos conceitos de Nietzsche colocando neles o seu próprio filosofar. Contudo, não pretendemos analisar as ressonâncias conceituais do pensamento nietzscheano sobre o deleuzeano. Desejamos tão somente que, a partir de Nietzsche e acompanhados de Deleuze, os conceitos aqui apresentados possam contribuir para a Psicologia, afirmando esta noção de uma Psicologia capaz de liberar a vida.

\section{VIDA FORTE}

Encontramos em Nietzsche, pelo menos duas maneiras muito precisas de definir a vida. Em primeiro lugar e sem metáfora alguma, a vida é caracterizada como um movimento nutricional, o qual, necessariamente implicaria sempre o sentido de aumento de poder, a partir de incorporação de força. "Chamamos 'vida' uma multiplicidade de forças ligadas por um processo de alimentação comum", que cresce incorporando forças alheias e alargando seu poder (NIETZSCHE, 2008a, p. 327; cf. p. 366). ${ }^{1}$

Em segundo lugar, é também essencial ao que é vivo, que possua um poder configurador, criador de formas a partir de dentro e explorando circunstâncias externas (NIETZSCHE, 2008a, p. 328). Porém, nestas duas caracterizações, ligando uma a outra, existe uma definição mais profunda, por assim dizer. Nas palavras nietzscheanas, tudo que é vivo quer, antes de tudo, dar vazão à sua força, ficando em segundo plano o problema da autoconservação (NIETZSCHE, 1992, p. 20). Notemos, isso implica que a vida não seja um processo harmonioso, o qual tende à paz e reconciliação, mas um constante embate, uma incessante guerra, em que 
diferentes forças se digladiam. Nutrir-se e criar formas são modos de fazer fluir a força e requer que elas lancem-se umas sobre as outras, de modo a incorporarem mais força. "Somos fecundos apenas ao preço de sermos ricos em antagonismos; permanecemos jovens apenas sob a condição de que a alma não relaxe, não busque paz [...]" (NIETZSCHE, 2005, p. 35, grifo do autor).

Precisamente, por força podemos entender, segundo destaca Deleuze (2001, p. 8), qualquer forma de apropriação e exploração de uma quantidade de realidade. O ser das forças está na realidade que a expressa, na quantidade de realidade que ela possui, de modo que ela é inseparável de sua expressão, de sua atividade. Poderíamos dizer que a vida é um acontecimento eminentemente estético, expressivo, diretamente ligado às forças que a compõem, enquanto estas são formas de apropriações, são modos de criação de realidade. Não se poderia, em primeira instância, separar a essência da força de sua atividade e de sua expressão, que é agir sobre outras forças. Assim, toda força é já força em relação, forças, no plural. "Qualquer força está, portanto, numa relação essencial com outra força" (DELEUZE, 2001, p. 13). A vida é feita de forças que se apropriam umas das outras e isso quer dizer também que ela própria é apropriada pelas forças, ou seja, a vida é inseparável das forças que a tomam, ela é objeto de ação das forças. "'Vida' haveria de ser definida como uma forma duradoura de processo dos estabelecimentos de força [...]" (NIETZSCHE, 2008a, p. 327, grifo do autor). Ora, parece plausível dizer que é próprio da vida querer tornar-se mais forte, já que seu processo é o de nutrir-se, tomar mais forças, estabelecer força. Estabelecer força ou tornar-se forte é criar realidade, produzir vida na vida. Fortalecer a vida é, então, de uma vez só, apropriar-se de mais realidade e produzir realidade: criar e tomar são idênticos quando se fala de forças vitais. Portanto, quando Deleuze define a força a partir da realidade que ela toma, não quer dizer que se conceba uma realidade preexistente às forças, mas, justamente, que a realidade é inseparável das forças que a possuem, sendo estas que irão produzi-la enquanto realidade viva.

\section{OS ENGOLFAMENTOS DA VIDA}

Porém, Deleuze coloca aí uma questão. A vida pode ser tomada por duas naturezas de força completamente diferentes: forças ativas, que dominam, se afirmam, se exercem, se exercitam e, mais ainda criam; e forças reativas, minguantes, que obedecem, que mantém, asseguram, lembram. De um lado, forças vigorosas, primaveris, germinais; de outro, forças do cansaço, outonais. As primeiras são criativas, agem, fluem. As segundas conformam-se, garantem um nível de vida orgânico, seguro, apenas o mínimo para uma sobrevida: são forças de permanência e conservação. Obedecer e dominar são os movimentos determinantes de duas estirpes diferentes de forças (DELEUZE, 2001, p. 64). Sendo duas linhagens, estas forças se fazem expressar por multiplicidades de forças em relação, que resultam, respectivamente em dois tipos de vida distintos. Quer dizer, existe um tipo de vida, um modo de viver correlativo aos tipos de força que nesta vida predominam. Nobre e escravo, ou ainda, forte e fraco, são denominações da expressão destas forças na realidade que as pertence, na vida que perfazem. Trata-se, então, de perceber que os tipos, escravos ou nobres, são sempre coletivos, são fabrica- 
dos coletivamente, por um montão de forças juntas, por um clã de forças. Não são tipos individuais, caráteres individuais, formadores de sujeitos, mas modos, que comportam muitas maneiras distintas de obedecer ou dominar e só incluem os sujeitos como peças de um agenciamento de forças.

Ora, se toda força, como descrevemos com Deleuze anteriormente, é sempre uma apropriação e exploração de certa quantidade de realidade, temos, então, que toda força tem uma capacidade de apropriar-se de outra força, formando um tipo de vida, expressando-se numa realidade que a caracteriza. Trata-se do "necessário perspectivismo, em virtude do qual cada centro de força - e não somente o homem - constrói a partir de si todo o mundo restante, isto é, mede apalpa, forma pela sua força" (NIETZSCHE, 2008a, p. 325). Toda força é, assim, portadora de um poder, que lhe caracteriza um modo de apropriação. Podemos dizer que o poder das forças está na vida que são capazes de expressar. Nietzsche (2009, p. 32) demonstra bem isso quando fala alegoricamente das diferenças de concepção de força e vida que existe entre a ovelha e a ave de rapina: para a primeira, que está na posição de ser abatida, a ave de rapina é má; por outro lado, a própria ave de rapina considera boa sua presa, na medida em que lhe serve de alimento. Para Nietzsche trata-se de dois tipos de vida distintos, que se fazem em função da força de que são capazes. Se é da força da ovelha a capacidade de balir e ser atacada, sua vida se constrói correspondentemente a esta força; ao mesmo tempo que, para a ave de rapina, que tem em sua força o poder de atacar, a vida se forma de outro modo, desta vez, baseada em poder se alimentar daquilo que suas forças entendem como bom.

Diante disto, o que parece problemático é compreender como se pode chegar a dizer que uma força é ativa ou reativa, como uma vida pode ser dita forte ou escrava: como escapar ao julgamento da vida? Aí é que Deleuze intervém, dizendo que obedecendo ou dominando, as forças estão no exercício deste poder que as caracteriza. Mesmo quando obedecem, as forças reativas não deixam de ser forças e estão em pleno exercício de seu poder (NIETZSCHE, 2009, p. 63). Uma força, ao entrar em relação com outra força, pretende dominá-la, apreendê-la, extrair as partes diferenciais desta, acrescendo para si uma quantidade de força (NIETZSCHE, 2008a, p. 322). Diríamos que as forças, ao dominarem outras forças, pretendem tornarem-se mais fortes, isto é, "quer ter em reserva uma "matéria" sempre renovada (ainda mais força)" (NIETZSCHE, 2008a, p. 334). Portanto, o que determina a estirpe a qual pertence uma força é o seu modo de exercitar aquilo que pode. O aparente impasse se resolve da seguinte maneira: não se pergunta mais se uma força é ativa ou reativa, se uma vida é absolutamente nobre ou escrava. Se toda força é força em relação, então a determinação de atividade ou reatividade depende do embate estabelecido entre as forças, depende da tensão gerada nos seus encontros. Trata-se, portanto, de um embate plástico, metamórfico e incerto. Uma vida pode, então, ser dita nobre (forte) ou escrava (fraca) na medida em que a tensão resultante do encontro entre as forças nela presentes seja capaz de criar ou de apenas conservar a vida, de acrescer forças ou mantê-las. Não se trata, pois, de um julgamento, mas de caracterizações que advém do poder metamórfico de que as forças se tornam capazes em seus embates. "O conceito de 'homem forte e homem fraco' reduz-se ao fato de que no 
primeiro caso herda-se muita força - ele é uma soma" (NIETZSCHE, 2008a, p. 433). Nobreza e força são imanentes de tal modo que tanto mais nobre um modo de vida quanto mais forças seja capaz de acumular e transmitir adiante.

Nietzsche $(2009$, p. $20 ; 29)$ fala da estirpe nobre de existência como uma casta guerreira e selvagem cuja bondade - ou justamente a nobreza - estaria na capacidade de fazer de seu poder um projétil, um bólido de energia e ação. Seria este também um sentido de integridade, de não-corrupção (NIETZSCHE, 1992, p. 170), ousar não intercalar a força com valores limitadores de seu poder, produzir um corpo em que a força está colada àquilo que pode. Deste modo, aquilo pelo qual a vida da estirpe nobre sustenta a vida é a possibilidade de ser forte e aumentar seu caudal de força. Ser forte é necessariamente agir e fluir, fazer da força um fluxo libre e criador.

Contudo, o que Deleuze denuncia na forma de vida que prevalece em nós é que há um predomínio das forças reativas, ou do tipo de vida escravo. E talvez seja por isso sua ênfase em relegar às forças reativas a mais venenosa impotência. Há um aparente maniqueísmo em Deleuze (2001, p. 182) quando ressalta a potência das forças ativas, colocando as forças reativas como secundárias. Acerca disso, nosso entendimento é de que a questão de Deleuze é justamente assumir um posicionamento claro em favor de uma vida inventiva, não deixando a possibilidade de se ter uma interpretação meramente relativista, dialética ou débil de Nietzsche.

Ora, nos tipos nobres a força é uma ação imanente, criação imediata de realidade. "Um quantum de força equivale a um mesmo quantum de impulso, vontade, atividade [...]" (NIETZSCHE, 2009, p. 33, grifo do autor). Falando de outra maneira, não é um sujeito que flui a força, é a própria força que se coloca numa relação como sendo capaz de fluir aquilo que pode, produzir realidade e vida. Há, então, uma crua diretividade na nobreza, que a faz parecer violenta, embora não seja nada mais do que viva, forte. Deleuze (2001, p. 16) fala de uma agressividade natural do ativo. Trata-se de uma inocente violência presente na maneira nobre de exercitar sua força (BARRENECHEA, 2004, p.170), a qual parte de uma ética que não é a da conservação, mas a do acréscimo de mais força. Assim, não há interioridade para a força ativa, se entendemos o interior como um espaço definido por um envoltório que separa de um espaço exterior. "Exigir da força que não se expresse como força [...] é tão absurdo quanto exigir da fraqueza que se expresse como força" (NIETZSCHE, 2009, p 33). Será isso que Deleuze denominará mais precisamente como alegria da potência, preferindo este termo em relação à palavra poder. Então, isto que podem as forças ativas não é poder, mas potência (DELEUZE, 1994, p. 39). E potência é um aumento da capacidade de agir (DELEUZE, 2002 , p. 34; 57), alegria de fluir força, criar realidade. Deleuze (2002, p. 46) ainda define como sendo um aumento de perfeição da qual se é capaz de se apropriar e de ser afetado, de modo que perfeição significa quantidade de realidade, já que toda realidade é uma quantidade diferencial de forças compostas.

Porém, de outro lado, as forças reativas são estas que, compositoras de uma vida escrava, reconhecem seu poder apenas quando prescindem dele e, ainda, maldizem o poder criador das forças ativas. É que, é dita escrava toda vida 
que, dominada pela necessidade de conservação, separa as forças daquilo que podem (DELEUZE, 2001, p. 93). Além disso, há uma passividade ligada aos tipos de vida escravos, diz Deleuze, que é decorrência justamente de só agirem secundariamente e de prescindirem da ação decorrente do poder da força. Vejamos bem que, para Nietzsche $(2009$, p. 21$)$, conceber uma força que não pode agir é, além de ficção, um modo de odiar a ação, coisa típica dos chamados modos de vida sacerdotais e esta vida que assim se concebe acaba sempre agindo depois de sofrer, acaba sempre padecendo, sem nunca ser capaz de inaugurar uma ação. A força da ovelha, do animal de rebanho, está em sofrer, em agir secundariamente: a vida escrava se faz no momento em que, qualquer que seja sua força, seu poder se encontra em não agir e, então, limitar e separar a força daquilo que pode.

Expliquemos ainda de outra maneira. O que vai caracterizar cada encontro é a tensão de forças aí gerada, ou ainda, a "fortividade" - potência das forças, quantidade multiplicitária das forças - aí agentes. Tanto mais forte a experiência produzida pela vida quanto mais haja aí forças distintas: diferença não enquanto diferença entre duas forças (comparação) ou oposição entre elas (dialética), mas como variação intrínseca de força, decorrente da tensão dos encontros. Ora, as experiências deixam marcas, mas estas marcas precisam ser abandonadas para que se possa seguir o fluxo inventivo da vida, o fluxo propriamente nobre da vida. Sobre isso, Deleuze (2001, p. 170) e Nietzsche (2009, p. 44) destacam que deve intervir a ação ou prevalência das forças ativas, criadoras e agressoras, atuando como produtoras do esquecimento das marcas deixadas pelas experiências. O que propriamente Deleuze destaca é que o esquecimento é função fundamental das forças ativas, enquanto são elas as forças criativas e as capazes de produzir novas experiências vitais. Por um lado, o esquecimento é uma consequência natural da ação das forças ativas, mas, por outro, este esquecimento deve ser ação deliberada de se impedir que as marcas se estagnem ou se sedimentem demasiadamente, formando uma memória para as forças, tornando-as pouco a pouco incapazes de abertura e sensibilidade para novas tensões. Precisamente deste modo é que a vida vai sendo cercada pelo fechamento da memória, pois toda experiência é sentida uma segunda vez, ou seja, é ressentida, decalcada sobre os novos encontros vitais. "Ressentimento designa um tipo em que as forças reativas imperam sobre as forças ativas. Ora, elas podem imperar de um só modo: deixando de ser agidas" (DELEUZE, 2001, p. 168). Em outras palavras, o ressentimento é o ponto em que as forças de conservação, manutenção e sobrevida prevalecem sem serem agredidas pelo esquecimento promovido pelas forças ativas. E talvez seja possível dizer em termos políticos que o ressentimento é a modulação afetiva característica dos tipos reacionários, cujas ações são sempre marcadas pelo conservadorismo, pelo poder de impedir a vida de tomar a realidade.

É a partir do momento em que as forças reativas escapam à ação das forças ativas, fazendo a vida ser invadida pela memória das marcas, que nasce o ressentimento, como atividade do tipo que sente sempre de novo, incapaz de esquecer. Deleuze (2001, p. 187) chama a atenção para o fato de este ser o primeiro momento da instalação do ressentimento. Depois disso, num segundo momento, mais grave, as forças reativas, ao invés de permanecerem como meras 
asseguradoras passam a opor-se às forças ativas, consolidando-se como tipo de vida, apropriando-se desta. O primeiro momento Deleuze chama de topológico: as memórias, ao invés de permanecerem em seu lugar, invadem os encontros de novas forças, interpondo-se entre as forças, tornando as experiências apenas formas de recognição, recaptação das forças dentro de imagens. Nós chamamos isto de primeiro engolfamento da vida.

O segundo momento do ressentimento, para Deleuze, é aquele em que as forças reativas conseguem assentar-se na forma de um tipo de vida, a partir do momento em que, não sendo agidas pelas forças ativas, opõem-se a elas e criam uma imagem fictícia da vida, na qual é possível que as forças sejam separadas de sua ação, isto é, daquilo que podem. O ressentimento é um adoecimento da dinâmica belicosa das forças e aparece quando não há possibilidade de prevalecer a ação agressiva das forças ativas (DELEUZE, 1981, p. 23), não há possibilidade agir e criar realidade. $\mathrm{O}$ ressentimento instala, então, uma estranha lógica de funcionamento: em sua impotência de agir, as forças se tornam passivas; incapazes de esquecer e exercitar aquilo que podem, as forças esperam ser alimentadas, ser nutridas de força. Pedem que lhes dêem força, que façam por elas o seu exercício de fortalecer-se. Mas, neste padecimento manso, se tornam capazes de acusar, de imputar culpa, maldizendo a ação, justificando sua impotência na ação alheia, responsabilizando a ação dos potentes por sua debilidade de forças (DELEUZE, 2001, p. 177-179). Forma-se uma passividade acusadora, maledicente e mendicante ao mesmo tempo e, além disso, incute-se à vida uma necessidade de justificação, de explicação para a ação das forças.

Ora, é esta a separação das forças daquilo que podem numa relação de forças, é isso a separação da vida das forças que a constituem. E é aqui também que se definem as forças reativas como sendo forças cujo poder está em limitar as forças ativas (DELEUZE, 2001, p. 85). Torna-se típico da vida escrava acreditar ser possível não agir quando se é tomado por uma força, criando-se para isso uma "fábula da liberdade inteligível", na qual se concebe a ação primeiro como possibilidade e não como realidade imediata (NIETZSCHE, 2005, p. 45). Toda força implica um poder de agir desta força sobre outra força. Mas, para o tipo escravo, a ação da força e a capacidade de criar ou produzir realidade são escolhas. A vida escrava é aquela em que a força sempre se rebate sobre um anteparo de impotência, colocando-se um limite à força, transformando-a em força reativa. A força que teria como lugar ou 'meio natural' o mundo, a realidade, o fora, torna-se força interiorizada. Nietzsche $(2009$, p. 67) chama esse momento de interiorização do homem, criação e crescimento disso que se entende por alma. As forças que não ganham a exterioridade do mundo voltam-se para dentro e, ao invés de criarem a vida, criam uma vida interior. Deste modo, a força se encontra distanciada daquilo que pode. "Interiorizar-se, virar-se contra si, é este o modo pelo qual a força ativa se torna realmente reativa" (DELEUZE, 2001, p. 192). Notemos bem, que é a força ativa que é interiorizada e só neste momento transformada em força reativa.

Contudo, é só a partir do momento em que se supõe uma força que escolhe agir e poderia não agir, ou não ter efeito e expressão, que se pode estabelecer o sentido de culpa (NIETZSCHE, 2006, p. 45). Tendo-se pré-concebido a ação 
como possibilidade psicológica, mental ou abstrata, se a transforma em possibilidade, imagem de ação. Ora, a ação ou criação de realidade por parte da força, quando concebida como escolha subjetiva é uma ficção, mas esta ficção não deixa de ter efeitos reais sobre as forças ativas, diz Deleuze na mesma passagem. É aí que a vida fica num golfo, cercada e cerceada, fazendo suas forças ganharem um movimento circular, que transita entre a memória do vivido e o rebatimento das forças sobre a impotência. Assim, a partir da interiorização da força, se imprime culpa à vida, se a torna injusta, passível de ser explicada; culpa esta que, derivada de uma acusação, só pode recair sobre um sujeito, sobre seres individuais. Somente quando se mistifica as forças da vida é que aparece a culpa, tal como sendo a força de um sujeito que é mal porque agiu e poderia não ter agido. É isto a chamada má-consciência, que entendemos como segundo engolfamento da vida. Ao ser interiorização da força fabrica a má-consciência enquanto potência da força virada contra si própria. Deleuze (2001, p. 193) destaca que, uma vez que a força ativa é privada de sua efetivação real, ela muda de sentido, transformando-se em dor. Aqui, compreendemos que mudar de sentido significa, para a força, além de se tornar interior ao invés de exterior e de ser feita reativa em lugar de ativa, ganhar uma nova maneira de sentir, uma nova, porém, adoecida sensibilidade. Intervém aí um princípio para explicar a vida, poluir o sentido direto das forças ativas; um princípio que pode ser o Bem, a própria justiça, a ciência, a verdade, ou ainda, contemporaneamente, a felicidade.

O duplo engolfamento da vida com o par ressentimento/má-consciência torna a vida repetição circular de experiências ou recaptação das experiências criadoras sob a forma das marcas e apaziguamento ou paralisação das forças pela culpa, paralisação do "fortivo" mar da vida e sua conversão em putrefata poça de água parada.

Em vez da unidade de uma vida ativa e de um pensamento afirmativo, vemos o pensamento dar-se por tarefa julgar a vida, de lhe opor valores pretensamente superiores, de a medir com esses valores e de a limitar, a condenar (DELEUZE, 1981, p. 18).

O ressentimento acusa para fora, condena a potência alheia, mas a má-consciência acusa para dentro, sedimenta a culpa, transforma a força de criação em um poder de aleijar-se, produzir contradição, voltar a potência contra si, de modo a fazer esta potência virar poder. Poder que é sempre tristeza (DELEUZE, 1994, p. 39), maneira típica dos tiranos de exercitarem aquilo que podem. "Tudo que envolve a tristeza serve à tirania e à opressão” (DELEUZE, 2002, p. 61).

Por isso é que Deleuze destaca um elemento plástico das forças. Há uma potência de tornar-se ativo e o poder de tornar-se reativo, um "devir-ativo" e um "devir-reativo" (DELEUZE, 2001, p. 83), os quais irão depender do embate de forças travado. Ora, uma força nunca existe separada de outra(s) das quais ela se apropria ou que dela se apropriam. Deste modo, não se trata de um julgamento das forças, mas de sua distinção, conforme são sempre forças multiplicitárias. Se ativo e reativo fosse de fato um julgamento das forças, assim como forte e fraco um jul- 
gamento das vidas, seria preciso que aí houvesse uma classificação essencialmente individual das vidas e das forças. Mas, na medida em que as forças são diferenciadas em função de sua multiplicidade - ou, o que dá no mesmo, em função de suas relações - é preciso encontrar a diferença das forças somente no complexo que formam. Ativo e reativo são devires, isto é, constituem-se como qualidades dependentes de uma multiplicidade complexa. Sendo devires das forças, também as vidas devém fortes ou fracas: há uma abertura incerta para ambos os casos.

Além disso, é preciso reiterar que não se pode chamar este dinamismo plástico das forças de dialético, pois as forças não fazem um jogo de revezamento e/ou oposição entre si, mas embates, nos quais as forças germinais são primeiras. Ao se avaliar as forças a partir de sua complexidade, se está necessariamente falando de uma avaliação social e coletiva dos modos de vida produzidos pelas forças. Isso equivale a nos perguntarmos pela natureza da maneira de viver que estamos produzindo em nosso tempo, em nós, na medida em que compomos um social. É uma avaliação, sobretudo, política e ética.

\section{A Psicologia da Vontade}

Assim, chegamos finalmente à discussão sobre Psicologia. Para tanto, é preciso compreendermos um outro elemento constituinte da força. Deleuze afirma que a força contém, junto daquilo que pode, o elemento da vontade. Desde o início falamos da pretensão das forças em tornarem-se mais fortes, em apreenderem mais forças. E exatamente isso a vontade, este ímpeto que, segundo Deleuze (2001, p. 76), completa a força em seu poder, sem que isso signifique que esta vontade seja extrínseca à força. A vontade é isto que permite à força lançar-se sobre outras. "É, portanto, sempre pela vontade de poder que uma força se abate sobre outras [...]" (DELEUZE, 2001, p. 79). Mas, aí mesmo, Deleuze alerta que não se deve compreender a expressão vontade de poder como se a força desejasse o poder. Diz ele que, se separar a força de sua vontade é uma abstração impossível, misturá-las numa identidade tampouco é menos perigoso. Ora, quando de uma relação de forças, a potência das forças já lhe pertence completamente, realmente. Isso que elas podem já é posse atual e real, ou seja, às forças não falta nada, elas são já várias, não carecem de potência e nisto já se encontra a ação da vontade. O que as faz querer mais forças é a vontade, mas não tomada do ponto de vista antropomórfico, ou consciente, como diz Deleuze (2001, p. 128). E a vontade de poder um desejo de afirmação da potência diferencial da força (DELEUZE, 2001, p. 17), mas desejar não é almejar, aspirar (NIETZSCHE, 2008a, p. 337) pelo poder. As forças não desejam porque algo lhes falta, mas porque querem mais forças para constituir sua composição. Vontade de poder é vontade de tornar-se mais forte, desejo por mais força na vida: tensão vital intrínseca à potência das forças.

Assim, é um desejo do transbordamento da força, de elevação de potência. Se interpretarmos a vontade de poder como desejo de poder, já estamos inteiramente olhando para o poder do ponto de vista da vida escrava, a qual justamente almeja uma potência que ela inveja, que ela odeia ao mesmo tempo em que ama, porque não a possui. Só do ponto de vista das forças reativas é que o poder se 
torna um objeto ou substantivo a ser adquirido exteriormente. Precisamente, as forças todas têm um poder, mas só nas forças ativas essa potência é já intrínseca e sua vontade é de fartura, transbordamento. O poder não é objeto da força, ele já está na força, seja ela ativa ou reativa. É pela ficção do ressentimento e da má-consciência que a vontade se torna uma aspiração pelo poder como objeto ou ainda substância que lhe falta. Quando se toma a potência como objeto é que se confunde a criação com a adaptação, a invenção de modos de viver, com a adoção de imagens de poder, baseados em valores estabelecidos, como honrarias, dinheiro, poder social, precisa Deleuze (2006a, p. 158). Torna-se, então, a potência uma coisa recognoscível e branda e não uma criação. Para a vida escrava o poder é uma imagem de poder que se almeja segundo os valores que referendam este poder externo às forças. A potência decai eticamente e vira poder. A vontade decai politicamente e se torna ambição interna de um sujeito.

Tão logo, na expressão vontade de poder, é preciso entender "poder" como sendo um verbo e, além disso, como afirma Nietzsche (2008a, p. 334), como sendo antes um sentimento de poder "a vontade de poder é a forma de afeto primitiva, todos os outros afetos são apenas configurações suas." (NIETZSCHE, 2008a, p. 348, grifo do autor) Então, o que faz, segundo Nietzsche (2008a, p. 330, grifo do autor), uma força abater-se sobre a outra é "o sentimento de tornar-se mais fortalecido, independentemente da vantagem da luta". A partir disso é que vamos tendo a clareza de que a vontade está na força, mas o poder não é algo externo e sim componente da força enquanto potência real, intrínseca. Por isso Deleuze (2001, p. 78) sintetiza “A força é quem pode, a vontade de poder é quem quer”, de tal modo que o poder já está compreendido na força como potência e sentimento intrínseco, e a vontade está na força como ímpeto imanente de aumentar este sentimento de potência. Desta forma, quando se diz de um sentimento de poder, se fala menos de um sentimento do tipo consciente e mais de uma modulação da sensibilidade, "um poder de ser afetado" (DELEUZE, 2001, p. 94).

É importante compreender que a vontade tampouco é causa da força, isto é, não se trata de uma vontade consciente, que move a força tal como uma mão lança uma bola. Se fosse assim, a vontade estaria de um lado e a força de outro, como sendo seu objeto. Ao contrário, a vontade de poder constitui-se imperceptivelmente, como móvel da força, mas inseparável da força, imanente a ela, do mesmo lado que ela. É somente quando a força fica interiorizada, que sua vontade se torna algo oposto, que fica de outro lado, que não o da própria força, confrontando-se com ela. Para Deleuze (2001, p. 97) a vontade de poder precisa ser entendida "em primeiro lugar, como sensibilidade das forças e, em segundo lugar, como devir sensível das forças". Podemos então dizer: o estudo destes modos de ser afetado e desta sensibilidade das forças é que constitui a Psicologia enquanto 'morfologia da vontade de poder'. Uma Psicologia da vontade de poder implica uma avaliação daquilo que constitui as sensibilidades, enquanto são estas as produtoras de vidas potentes ou poderosas, vontades imanentes ou destacadas das forças. Não se trata de uma Psicologia dos afetos individuais e humanos, mas do estudo-ação de uma afetividade transversal, que compõe não apenas a nós, homens, mas, mais profundamente, a tudo aquilo que é vivo e potente. Segundo esta concepção, a vontade de 
poder é, nas forças, o seu princípio plástico, um "princípio 'intensivo"” (DELEUZE, 2006a, p. 162), o qual, como vontade, quer fazer da vida algo cada vez mais forte, mais intenso, elevado à enésima potência, que é a potência de criar.

Portanto, ao tratar a Psicologia como estudo dos processos da vontade de poder, Nietzsche está transformando esta Psicologia num trabalho crítico e rigoroso de diferenciação das forças que compõem uma vida. Ele estaria, neste ponto, denunciando a mendaz bondade da vida escrava, que toma como bom aqueles que menosprezam a potência da vida, fazem da bondade a abstenção da potência por parte da força, tornando mansa e sem efeitos, inexpressiva. Disso é que Nietzsche (1992, p. 29) ainda completa a sua definição de Psicologia como sendo "teoria na qual os impulsos bons derivem dos maus". Entendamos bem: o que se chama de impulso mau só o é dentro do olhar reativo, ou seja, deste ponto de vista, afetos chamados, de ganância, egoísmo, ânsia de domínio, recebem estes nomes depreciativos na medida em que são interpretados por uma vontade, cuja potência está como objeto da vontade. Mas, para uma vontade de poder preenchida de sua potência, tais afetos são condições necessárias ao fortalecimento, criação, estabelecimento da vida em sua força máxima e, neste sentido, já não são ganância, egoísmo, mas faces diferenciais da vontade. Define, então, Deleuze (2001, p. 128), que "O que a vontade de poder quer, é tal relação de forças, tal qualidade de forças". E acrescenta, que a vontade de poder, em seu nível mais elevado, ou seja, quando ela é capaz de efetivar e afirmar uma vida em sua potência plena, não consiste em tomar, mas em dar e criar. (DELEUZE, 2006a, p. 158) Como diz Nietzsche (2008a, p. 329) “o essencial no processo de vida é justamente o poder [Gewalt] imensamente configurador, criador de formas a partir de dentro." O abater-se de uma força sobre outra força, em primeira instância, consiste em tomar mais força. Porém, sendo que o atacar é poder típico de uma força ativa e que também é próprio destas forças já estarem repletas de força, tendo herdado muito poder no exercício de agir, então, sempre há neste agir este poder configurador, esta capacidade de dar forma, dar valor, dar sentido. O criar é necessariamente dar, porque o apropriar-se de uma força decorre sempre de um excesso, um transbordamento de força, "de uma saúde florescente, rica" (NIETZSCHE, 2009, p. 22), que se extrapola e se direciona sobre outra força; excesso este que advém do poder de exercer força, realizar o poder. Então, nesta realização, neste agir, sempre há transformação, criação de nova forma, colocação e doação de força. Daí, se poderia dizer, numa espécie de generosidade que subsiste em toda vida forte e por trás de sua aparente ganância, violência e egoísmo. "A alma nobre dá como toma, com o passional instinto de retribuição que habita no seu fundo" (NITZSCHE, 1992, p. 181).

Então, fica clara, a conceituação de Psicologia como estudo morfológico vontade de poder e a relação desta noção com a afirmação de uma vida forte. A vontade de poder não é um motivo para vida, isto é, ela não justifica a vida e nem a explica ou lhe impõe metas. Porém, podemos dizer que ela seja a maquinação plástica da vida, que permite a sua diferenciação e a sua avaliação, pois é segundo a vontade de poder que a vida se torna forte ou escrava. Ora, Deleuze (1981, p. 22) diz que é também pela vontade de poder que uma força obedece. Neste caso 
é que a vida aí produzida se faz desejosa por um poder que está estabelecido nos valores dominantes e instituídos. Por outro lado, é pela vontade de poder também, quando ela se constitui como força de afirmação da diferença de uma força, que se cria vida, tornando-a leve e forte. "Criar é aligeirar, é descarregar a vida, inventar novas possibilidades de vida." (DELEUZE, 1981, p. 19) Se falamos aqui de uma Psicologia da vontade de poder, é porque não fazemos da Psicologia a uma ciência do "eu" ou estudo da interioridade psíquica dos sujeitos. Já vimos que força e vontade são posses de um "eu interior" apenas na medida em que se encontram engolfadas pelo ressentimento/má-consciência. Diversamente, como Deleuze (1981, p. 23) precisa, trata-se de uma "psicologia do cosmos", ou seja, estamos falando das forças que compõem a vida e de sua capacidade de afetar - de mobilizar mais forças - e, deste modo, criar. Psicologia não mais como ciência do psiquismo antropomórfico, mas como estudo-ação das transformações das forças e das vontades, enquanto sejam vontades de potência ou de poder: analítica diferencial da potência das forças de criar vida ou conservá-la.

Por isso é que Deleuze (2001, p. 82, grifo do autor) também diferencia duas naturezas de vontade de poder, consoantes com os tipos de força e os modos de vida decorrentes, de tal modo que "[...] afirmativo e negativo designam as qualidades primordiais da vontade de poder". A vontade de poder afirmativa é aquela que, na força, age de modo a querer a efetivação daquilo que ela pode, elevando sua potência. Em sua forma fortalecida, a vontade é alegria, criação (DELEUZE, 2001, p. 127). Logo, a afirmação será sempre a afirmação da singularidade ou da diferença da força: afirmar é exercitar o que a força pode. Entre a afirmação e a negação, a diferença consiste na posição que o "dizer sim" toma: na afirmação o "sim" vem como ato inaugural, começo de efetivação de uma força, expressão não mediatizada da diferença. A força afirmativa é aquela que se coloca como diferença em si mesma, não se restringindo a dar-se como um "não-ser" para um ser. Ela "primeiro e espontaneamente, de dentro de si, concebe a noção básica de 'bom', e a partir dela cria para si uma representação de 'ruim" (NIETZSCHE, 2009, p. 28). Sua diferença, seu poder não nasce da negação e oposição. Por outro lado, a negação, típica da vontade de poder negativa, o "sim" vem sempre somente depois de um "não", quer dizer, necessita-se negar o poder de uma força, para firmar-se e para acolhê-la. Para o tipo escravo, dominado por forças reativas, o "sim" só advém depois de opor-se, negar a ação livre das forças ativas. Só é aceitável uma força que teve seus efeitos amortecidos, primeiramente negados, separada daquilo que pode: afirmação de si que acontece a partir da negação alheia (DELEUZE, 2001, p. 85), diferença que mediatiza pelo "não-ser". Contudo, a vida forte, preenchida de potência, é aquela em que, diz Deleuze (2001, p. 130), se tem uma vontade de poder capaz de manter a diferença entre as forças criativas e as forças de conservação, mantendo estas últimas em condição de não se excederem. Isto significa permitir que as forças reativas tragam algum nível de segurança, sem se sobressaírem com o poder do ressentimento e da má-consciência. A partir de uma vontade de afirmação, a vida é avaliada do ponto de vista daquilo que é forte, da potência de criar. Neste nível, a força se apropria de mais forças, porém, doando força. O lançar-se sobre outra força é já um doar e criar força. 
Assim, encontramos duas possibilidades ético-políticas para a Psicologia da vontade de poder. De um lado ela pode ser uma ciência da afetividade tomada como dinamismo enclausurado de um tipo-homem enfraquecido, um saber das memórias, das marcas e traumas. Mas, a partir de uma vontade de poder afirmativa, esta que Deleuze diz ser a face ainda desconhecida da vontade de poder (DELEUZE, 2001, p. 259), a Psicologia tem como se tornar um saber e um fazer que vem em favor de uma vida nobre, potente. Tomando como seu material a natureza plástica da vontade de poder, esta Psicologia se coloca, pois, o trabalho de diferenciar as forças e afirmar a sua diferença, isto é, sua potência.

\section{AfirmaÇão de uma VIDa FORTe}

Entretanto, a questão que permanece é: como escapar ao ressentimento e à má-consciência? Como não deixar que a vida fique cercada? Como inocentar a vida da culpa e do julgamento?

Primeiramente, podemos ver que, quando se privilegia a potência das forças ativas e sua vontade de poder afirmativa, já se inicia uma transmutação da vida. Ora, afirmar é necessariamente afirmar a diferença da força enquanto potência de agir, ou seja, afirmar está ligado a um exercício constante de um ganho de mais forças, mais diferenças. E mais profundamente, a afirmação implica que se exercite constantemente a potência de criar das forças. A vontade de poder, enquanto se afirma na potência de criar, é já uma espécie de alegre dissolução dos tristes poderes e se encontra assim "inteiramente justificada em sua obra" (NIETZSCHE, 2009, p. 69), porque não prescinde daquilo que pode. O que a força pode passa a ser, assim, um "centro de metamorfose" e "uma idiossincrasia de forças" (DELEUZE, 1997, p. 152).

Deleuze (1997, p. 163) diz haver, na consolidação da vida escrava, "um par infernal", "o Déspota e o Sacerdote, terríveis 'juízes' da vida", os quais fingem ser a tristeza uma promessa de alegria, fazendo com que haja poder na aflição e no rebaixamento da potência. É um par poderoso que vê beleza e valor em se aleijar a vida e em retardar a potência de agir das forças. E já encontramos aí o sentido mais contundente de corrupção: a vida que se quer sem força, que forja a impotência da força e por isso ambiciona o poder. É o caso, ainda, em que a vida fica endividada, ela deve algo, porque se vê - se sente - culpada e destituída de sua potência. A função ressentimento/má-consciência cria uma maneira de sentir corrupta, a qual encontra seu poder em agiotar as forças vitais. Neste sistema de juízo, as vidas são repartidas em lotes meritórios individuais (DELEUZE, 1997, p. 146), que designam o poder de cada um em função de sua conformidade ao $\mathrm{Bem} / \mathrm{Mal}$ que a vida reativa concebe. Diante disto é que Deleuze (1997, p. 153) fala de uma outra e nova justiça, a "justiça da crueldade" em que, ao invés de tolher as forças e desprezar sua potência, as faz existir, isto é, as faz criar realidade, afirmar sua diferença. O sistema da crueldade é um sistema de afirmação de uma potência belicosa, é um sistema físico, define Deleuze (1997, p. 148), um sistema em que o constante exercitar das forças ativas torna a vida leve. 
Mas resta ainda um ponto a esclarecer: como a vontade de poder, podendo ser negativa ou afirmativa, chega a devir-afirmativa? O que libera as forças e a vontade de poder, de modo a afirmá-las? Neste momento é que intervém, talvez a mais original apropriação deleuzeana dos conceitos de Nietzsche: o eterno retorno como eterno retorno da diferença. Segundo Deleuze (2001, p. 103), é o eterno retorno o grande seletor de forças, o grande filtro avaliador e seletor. O próprio Nietzsche (2008a, p. 508, grifo do autor) o diz claramente. "O pensamento do eterno retorno como princípio de seleção, a serviço da força". O eterno retorno, trata da ideia de que o mundo é, simultaneamente, eternidade e devir, "ao mesmo tempo uno e vário" (NIETZSCHE, 2008a, p. 512). Precisamente, o mundo é apenas um, mas um só grande devir, um grande paradoxo retornando eternamente por força dos devires. Mais do que uma sucessão de mudanças, que fariam do mundo algo de infinito, num desenvolvimento constante e linear (NIETZSCHE, 2008a, p. 511), trata-se de captar no mundo um grande processo cíclico, o qual promove grandes retornos, a partir de sua incessante metamorfose "[...] um mar de forças tempestuosas e afluentes em si mesmas, sempre se modificando, sempre refluindo, com anos imensos de retorno" (NIETZSCHE, 2008a, p. 512).

Vemos que é uma concepção de mundo, na qual tudo o que existe está em incessante transformação. Mas estas várias transformações incessantes são também uma só, fazendo com que, em um certo ponto, o mundo volte à sua primeira metamorfose, à sua diferença primeira e eterna, ao seu primeiro devir. Não são devires sucessivos, encadeados como um trem, senão um só devir que o mundo se torna segundo inumeráveis devires simultâneos e contemporâneos, justamente, de forma tempestuosa. Então, um só grande devir que se efetua no processo de devir milhares de vezes nas milhares de coisas e acontecimentos, até que complete seu ciclo e torne-se, finalmente, o primeiro devir que sempre esteve devindo em cada tornar-se, para daí poder recomeçar, devindo uma única vez em todos os devires que o farão. O mundo "ele torna-se, passa, mas nunca começou a tornar-se e nunca cessou de passar - ele mantém-se em ambos [...]" (NIETZSCHE, 2008a, p. 510, grifo do autor).

“[...] um devir que não conhece nenhum tornar-se satisfeito, nenhum fastio, nenhum cansaço: este meu mundo dionisíaco do criar eternamente a si mesmo, do destruir eternamente a si mesmo, este mundo misterioso da dupla volúpia [...]" (NIETZSCHE, 2008a, p. 513). Mundo-tempo, devir-mundo do tempo. Assim, o que volta eternamente é a diferença e, portanto, falar de um ciclo, não significa que tudo o que aconteceu voltará a existir. Diversamente, o eterno retorno do devir dá a entender que a diferença voltará para tudo o que existir, ou seja, a diferença sempre deverá se afirmar. "O Mesmo não volta, é o voltar apenas que é o Mesmo daquilo que devém" (DELEUZE, 1981, p. 30). Assim, não são as coisas, as formas e seres que voltam a existir, é a diferença e a potência que eles devieram que retorna eternamente. Sendo eterno, o retorno é também sempre já atual, presente, ou seja, o devir retornará, porque já está devindo agora, porque é contemporâneo e simultâneo ao mundo. Tampouco, como diz Deleuze (2006a, p.161), é o mundo todo que volta, o eterno retorno não seria total nem eterno, mas seria um eterno retorno de ciclos parciais porções de forças ativas que retornam. Esta concepção, 
nas palavras nietzcheanas, justamente vem desconstruir a possibilidade de que haja um fim, uma meta ou razão para a vida. Com o eterno retorno, escapa-se de um mundo que objetive chegar a um ponto máximo de equilíbrio (NIETZSCHE, 2008a, p.510), de conclusão da vida. Isto tampouco implica que o mundo seja infinito, uma linha sem fim, mas exatamente que seu limite é a diferença em que ele se transforma a cada retorno. O mundo não tem meta e nem é ilimitado: ele é uma teimosa diferenciação. Portanto, se a vida não possui um estado final, meta ou objetivo inicial, o devir tem valor igual em cada momento (NIETZSCHE, 2008a, p. 358), podendo valer, em cada momento, para todos os momentos. Devir e eterno retorno se confundem e se identificam, mas se identificam na diferença que constituem a cada mundo ou a cada acontecimento-diferença que fabricam. O eterno retorno é a igualdade das potências, que se afirmam a partir de cada força efetivada que constitui a vida. Assim, o devir atesta a eternidade da diferença. "Regressar é o ser do que devem. Regressar é o ser do próprio devir, o ser que se afirma no devir" (DELEUZE, 2001, p. 39, grifo do autor).

Então, como rigoroso afirmador e seletor, Deleuze diz que o eterno retorno promove duas filtragens nas forças. Em primeiro lugar, as forças são filtradas segundo a sua vontade de poder, ao passarem pela seguinte prova. "O que quiseres, queira-o de tal maneira que também queiras o eterno retorno." (DELEUZE, 2001, p. 104) Isso quer dizer: desejar a ponto de querer que aquilo que se deseja retorne infinitamente, devenha eternamente a diferença que é, e que se possa ter de modo transbordante, um número infinito de vezes. Em outras palavras, o eterno retorno exige que a vontade seja sempre íntegra, incorrupta; para o eterno retorno não há "meios quereres" (DELEUZE, 2001, p. 104). O eterno retorno, em sua primeira seleção, retém apenas as forças cuja vontade de poder é um bólido fluido e feroz. As forças possuidoras de uma vontade negativa e malsã não passam por esta seleção. Por isso o eterno retorno não faz tudo voltar, mas apenas permite voltar a diferença e a vida forte. "[...] desigual é a seleção do eterno retorno" (DELEUZE, 2006a, p. 163). Assim, se atribui ao eterno retorno, muito mais um movimento centrífugo do que meramente cíclico. Neste movimento centrífugo, o eterno retorno estaria expulsando tudo o que é impotente e moderado demais (DELEUZE, 2006a, p. 165). Este momento deixa para trás muitas forças reativas. O eterno retorno faz cair fora da vontade tudo aquilo que não permita que ela crie, "efetua a equação, querer $=$ criar" (DELEUZE, 2001, p. 105).

Porém, alerta Deleuze que é sempre preciso haver uma segunda prova imposta às forças: algumas forças reativas, mais astutas, passam pela primeira seleção do eterno retorno. Esta segunda seleção das forças consiste em fazer embater o eterno retorno com o limite próprio da vontade. Aí, a questão passa a ser: esta vontade de poder tem ela tal intensidade e tal nobreza que seria capaz de querer terminar-se, concluir-se? "[...] já não se trata, pelo simples pensamento do eterno retorno, de eliminar o querer que sai fora deste pensamento; trata-se, pelo eterno retorno, de fazer entrar no ser aquilo que aí não pode entrar sem mudar de natureza" (DELEUZE, 2001, p. 107). Se no primeiro momento a seleção tinha um tom mais negativo, no sentido de eliminar algumas forças, agora, ao contrário, o movimento seletivo é pura afirmação da diferença. Na segunda seleção, trata-se de 
fazer entrar as forças capazes de metamorfose, transformação e, portanto criação de uma diferença para si. Logo, acabar-se, destruir-se não tem sentido de aniquilamento ou autoflagelação. Nesta segunda seleção, tudo aquilo que é reativo, que prescinde sua força e, portanto, não a exercita, torna-se incapaz de terminar algo, isto é, de levar uma força ao seu ponto de mutação. Daí, ser incapaz de terminar é o mesmo que ser incapaz de iniciar, de começar afirmando. Então, vemos do lado das forças ativas, sempre, pelo menos duas afirmações: o "sim" iniciático, primaveril, germinal e matinal, um segundo "sim", mais potente, mais combativo e feroz, que é o "sim" terminal, notívago, aquele que faz retornar o eterno retorno, o que faz vir de novo, em um devir, todos os demais devires desejados. Sendo assim, podemos ver que nenhuma vontade de poder, nenhuma força pode ser afirmativa e ativa se não contiver um poder de destruir, um desejo de destruição e, em especial, de autodestruição. É por isso que a autodestruição é dita uma operação ativa, uma "destruição ativa" (DELEUZE, 2001, p. 106).

"O eterno retorno transforma o negativo [...]" (DELEUZE, 2001, p. 131). Selecionar é, pois, afirmar uma potência em sua diferença radical. Diz Deleuze (1981, p. 33) que o eterno retorno promove uma repetição, mas é uma repetição que seleciona e liberta. Diferente do sistema instituído pelo ressentimento/má-consciência, a repetição do eterno retorno dá fim a tudo que deve, a tudo que arrasta dívidas, elevando a potência das forças ao seu limite. "Só volta a afirmação, só volta aquilo que pode ser afirmado [...]" (DELEUZE, 1981, p. 32). Deste modo, o eterno retorno torna o devir uma presença eterna, imanente, capaz de reinaugurar e revigorar as energias criativas das forças ativas. $\mathrm{O}$ eterno retorno permite fortalecer as forças ativas, devir-ativo. A seleção final ou a coroação das forças ativas se dá com a sua eternização sobre o devir: só o ativo pode ser eterno, porque só ele devém, leva a diferença a diferir. É a diferença a própria forma da eternidade. Por isso, afirmar uma vez a sua diferença, na lógica do eterno retorno, é afirmar por todas as vezes, eternamente. É, enfim, com o eterno retorno que a vontade de poder se torna vontade de potência e a vida se libera de qualquer interioridade, dívida ou engolfamento, a vida se inocenta.

Encontramos aí uma vida capaz de priorizar "a sensação de plenitude, de poder que quer transbordar, a felicidade da tensão elevada, a consciência de uma riqueza que gostaria de ceder e presentear" (NIETZSCHE, 1992, p. 173). Sem ser separada de sua natural e inocente agressividade, a vida não pode se realizar em sua máxima potência sem que haja uma espécie de combate. O combate, esclarece Deleuze (1997, p. 150), não é combate dual, dialético, o combate contra, mas a luta entre, na qual, ao invés de querer destruir - ou destituir - a potência de uma outra força, deseja-se incorporar esta força, para fazê-la sua de tal modo que as potências sigam íntegras, mas já compostas uma na outra. O combate, completa Deleuze (1997, p. 151), refere-se a uma potentíssima "vitalidade não orgânica", tão robustamente delicada quanto a de um bebê recém-nascido, portador de um "querer-viver obstinado, cabeçudo, indomável". Compreendemos, então, o combate como um exercício e afirmação das forças. Nietzsche então esclarece dizendo que esta força guerreira, típica da vida livre, é a capacidade de encontrar combates íntegros, entre vidas fortes que se vêem igualmente dignas em sua potência. Não é 
a capacidade de agredir para subjugar, mas de encontrar no confronto uma espécie de medida diferencial da própria potência. (NIETZSCHE, 2008b, p. 29) "Igualdade frente ao inimigo - primeiro pressuposto para um duelo honesto. Quando se despreza não se pode fazer a guerra" (NIETZSCHE, 2008b, p. 29, grifo do autor).

Aqui encontramos outro aspecto importante para uma Psicologia da vontade de poder: discernir muito claramente a violência da agressividade nobre. Para além de toda moral simplista, estes conceitos permitem compreender que a violência está, antes mesmo do gesto violento, na ação negadora e reativa, que consiste em desprezar a força alheia, rebaixá-la, para daí lançar um gesto destruidor. E desprezar a força é necessariamente desprezar a sua diferença de potência. A violência pressupõe uma violação da relação de forças, uma decomposição anterior ainda ao gesto violento. A agressividade nobre, diversamente, pede uma tensão intrínseca à relação de forças, cuja consequência não é mais a decomposição de uma das partes, mas o crescimento do sentido de potência que constitui a relação e envolve todas as partes. A agressividade distribui generosamente o aumento de potência, porque estabelece relações de força, ao invés de entronizar indivíduos poderosos.

A partir do combate vital do sistema da crueldade, encontra-se uma afirmação das diferenças tal como elas se constituem, cruas e agressivas, diretas; afirmação que refina, metaboliza, metamorfoseia as potências, elevando-as. Crueldade do eterno retorno, rigor "devirunlento" colocado à vida. No combate entre há a destruição ativa, que transmuta a negação da potência em afirmação: a crueldade é o outro lado da seletividade diferencial do eterno retorno. Na afirmação do combate, encontramos um meio de tirar da vida a gravidade própria da tristeza, do enfraquecimento e da condenação da força. Trata-se do combate como criador da tensão que é justamente capaz de imantar as forças à vida: combater entre para tecer uma generosa imanência. Frente à abstração mística da vida, coloca-se um ponto de agilidade física, afetiva, real. Assim, é através da cruel transformação do eterno retorno que a vontade de poder pode ser afirmação e que se encontra na vida uma inexplicada justeza, a inocência daquilo que se afirma desejando e deseja afirmando uma força, uma diferença.

\section{Conclusões para uma Psicologia que fortaleça a Vida}

Vejamos, então, como estas concepções se sedimentariam em nossa tarefa, aqui colocada, de pensar uma Psicologia voltada para a vida. Compreendamos, pois, um pouco daquilo que o próprio Nietzsche chama de Psicologia.

Segundo Giacoia Jr. (2001, p. 22) se Nietzsche se denomina o primeiro psicólogo da Europa é porque, em primeiro lugar ele rompe com uma tradição filosófica da época, que fazia da Psicologia um estudo das dinâmicas da racionalidade na consciência. Seria este um dos preconceitos aos quais a Psicologia estaria ligada, que mencionamos no início deste texto. Diz este autor, que a Psicologia nietzschiana teria vindo derrubar as bases metafísicas até então consolidadas para a ciência da subjetividade, as quais identificavam o psíquico e o consciente. Com efeito, Nietzsche (1992, p. 11) destaca que a maior parte do que se pensa dentro da consciência advém dos instintos, de uma "inteligência dos instintos" e não da 
própria consciência. Giacoia Jr. relembra que, além da colocação da vida psíquica para fora da consciência, outro aspecto que Nietzsche ataca na Psicologia é o de ela estar contaminada pelos modos de valoração dominantes na cultura, baseados em preconceber os afetos como bons e maus. Quer dizer, a Psicologia teria perdido, assim como a Filosofia, o fato de que os sentidos de bom e mau foram tecidos na história. Ainda nas palavras deste autor (GIACOIA JR., 2001, p. 55), Nietzsche ataca também a tradição do atomismo psíquico, segundo a qual a alma seria eterna e indivisível. Tão logo, a vida psíquica seria necessariamente plural, multifacetada e feita de uma dinâmica emaranhada de impulsos e afetos, sem se limitar a uma alma monolítica e identitária.

Este autor, porém, parece ignorar o fato de que, mesmo falando de toda uma vida instintiva, Nietzsche não identifica sua Psicologia ao estudo de um aparelho psíquico interior, cuja divisão se daria entre um consciente e um inconsciente. Se estamos certos em nossa interpretação, a desconstrução da identidade entre consciência e psique não implica necessariamente no estabelecimento de uma divisão desta última em regiões internas. Nosso entendimento é: a destituição da consciência do centro da alma tem por consequência a dispersão completa desta vida dos afetos para fora de toda forma individual ou subjetiva. Se Nietzsche diz : “o 'instinto' é a mais inteligente das espécies de inteligência até agora descobertas" (GIACOIA JR., 2001, p. 125), é para que tenhamos esta descoberta tomando como referência o processo transformativo e evolutivo da vida como um todo ou mesmo de uma cultura e de uma espécie ao longo do tempo. A consciência é certamente um órgão para Nietzsche, mas cujo aparecimento ocorreu tardiamente se considerarmos a longa história dos acontecimentos vitais.

Toda vida consciente, o espírito junto com a alma, junto com o coração, junto com a bondade, junto com a virtude: isso trabalha a serviço de que? No aperfeiçoamento maior possível dos meios (de nutrição, de incremento) das funções animais fundamentais: antes de tudo, no incremento da vida (NIETZSCHE, 2008a, p. 339, grifo do autor).

Além disso, temos que a consciência não se opõe a um inconsciente na forma de outra região da alma, porém, mais propriamente ao corpo, este entendido justamente como "um pensamento mais espantoso do que a antiga "alma"" (NIETZSCHE, 2008a, p. 332), tanto que raramente Nietzsche emprega o termo inconsciente. Para Giacoia Jr. (2001, p. 59), tomando-se como modelo o corpo estaríamos nos aproximando mais fielmente da verdadeira pluralidade que constitui o mundo dos afetos e instintos. Notemos, tão logo, que com estas derrubadas das pilastras da Psicologia, também se desmoronam os preconceitos morais que as fundamentam. A Psicologia se a-funda e, simultaneamente, se abre para um novo horizonte constitutivo: a possibilidade de pensar, não mais os sujeitos, as almas individuais, mas os modos de vida e suas forças componentes. Tece-se uma "subjetividade fora da mente", não mais voltada para "um homúnculo dentro do homem", mas para a complexidade de forças que se dobram e desdobram no mundo (SIMÕES et al., 2011, p. 356). 
Por estas razões, portanto, é que, aqui, demos preferência a falar de culpa e ressentimento como movimentos propriamente das forças da vida e dos tipos de vida e não de sujeitos ou sentimentos psíquicos, os quais são, como se viu, entidades de cunho moral, nascidas de uma dinâmica do ressentimento, da acusação e da interiorização do homem. Quer dizer, ao liberar a Psicologia da consciência, Nietzsche libera-a de toda concepção mentalista e interiorizante, abrindo-a para todo o processo e produção de vida. Em outros termos, a Psicologia não se restringiria à vida psíquica, esta entendida apenas como privilégio humano, mas se voltaria a estudar amplamente os fenômenos da vida. A favor deste nosso argumento, temos Vianna (1995, p. 31) dizendo que "a singular psicologia nietzscheana ao operar com as pulsões artísticas da natureza manifesta um inconsciente primordial o qual escapa às possibilidades de representação consciência”.

Pois bem, dentre estes fenômenos da vida estaria o surgimento dos sentimentos morais, cuja indagação pela sua história seria justamente a tarefa da Psicologia (NIETZSCHE, 2005, p. 43), uma vez liberada de seus preconceitos. Acerca disso, porém, Vianna (1995, p. 31) destaca que a Psicologia nietzschiana "está mais próxima de um peculiar método de interpretação do que propriamente de uma ciência constituída". Ora, enquanto modo de interpretação é que justamente esta Psicologia se faz como teoria da evolução da vontade de poder, tal como Nietzsche a definiu: são as vontades de poder surgidas na história, nas vidas que serão interpretadas e não os sujeitos.

Então, a partir do entendimento do embate dinâmico das forças e de sua vitalidade, encontramos, com efeito, uma nova forma de Psicologia, capaz compreender as diferenças e admitir que não há vida sem o embate e sem o combate entre as forças, os quais irão tensioná-las, devindo-forte a vida. Temos, pois, uma Psicologia assubjetiva, que quer inocentar da vida, a partir da avaliação da vontade de poder e da afirmação da potência das forças, mas conectando todo sentir humano aos processos vitais das forças em embate. Nas palavras de Naffah Neto (1994, p. 33) trata-se de uma Psicologia capaz de criar um "circuito nobre", uma composição dentro da qual as forças ativas prevalecem e "controlam as forças reativas".

Assim, deixamos aqui uma arriscada e, talvez, ousada proposição. Uma Psicologia capaz de liberar a vida, a partir do estudo rigoroso e da crítica da vontade de poder seria uma prática capaz de ensinar a lutar, entrar em embate. Rigor este, que se desenvolve na capacidade de distinguir com fineza e acuidade a natureza e os domínios das forças, a vida que elas constituem. Afinal, como vimos, a prova do eterno retorno promove sempre uma filtragem fina das forças reativas. Falamos, pois, de uma Psicologia forte, no sentido de que se apossa das potências da luta para permitir devir a vida, fazê-la novamente ágil e desenvolta, alegre e feroz. Seria, portanto, uma Psicologia que privilegia a crua fúria e o fluido humor das forças ativas, em lugar da lamúria mendicante da má-consciência e da tristeza mendaz do ressentimento. Aqui, para a constituição de uma tal Psicologia, caberia a percepção de Trevisan (2005, p. 57) de que é típico da "engenhosidade do ressentimento impedir que sua ligação aos valores morais seja posta em evidência". 
Quer dizer, uma tal Psicologia, enquanto trabalhasse no sentido de desmistificar a vida do peso do ressentimento, estaria também denunciando e desconstruindo a ligação existente entre a lógica de infecciosa do ressentimento e os valores morais.

Contudo, não se fala aqui de um desejo de uma vida sem dor. Não é isso a liberação da vida. Diversamente, a potência de combater se torna veículo de mutação e metabolização de qualquer dor. Se a interiorização da dor faz a vontade de poder desejar uma vida sem vontade, porque cria uma realidade em que toda força é convertida (invertida) em dor, a afirmação da diferença das forças faz a vontade de poder querer, ainda na dor, um outro poder na vontade. A afirmação libera a vida porque apreende - compreende - a dor como força que deseja sua potência e aí já se tem o início de um movimento transformacional. Ora, é o eterno retorno que, ao selecionar as forças ativas, dá à vontade de poder a liberdade de afirmar e de avaliar a partir da diferença, de modo a apreender da força aquilo que nela é potência. A dor, neste sentido, é força não agida, é força não afirmada, força que não deveio no eterno retorno. "Afirmar, é ainda avaliar, mas avaliar do ponto de vista de uma vontade que frui a sua própria diferença na vida, em vez de sofrer das dores da oposição que ela própria inspira a essa vida" (DELEUZE, 2001, p. 275).

Tomando por instrumento a natureza seletiva e "devirulenta" do eterno retorno, a Psicologia problematizadora das forças vitais entenderá, então, que é potente tudo aquilo que se deseja com a intensidade de querer voltar infinitas vezes, isto é, se uma força resiste voltando, é porque há aí uma diferença; porém, é ainda mais forte aquilo que, nas vidas, se torna capaz de ser levado ao limite, chegando a devir, tornar-se diferença. Será, portanto, pela força de afirmação e de transformação que a vida será feita leve, desprendida da culpa e de um princípio justificador. Estamos frente a uma Psicologia que, ao mesmo tempo, aligeira a vida e a afirma sobre a vontade de poder, tornando-a leve e forte, inocente e alegre.

Trata-se enfim, de produzir uma Psicologia vital, que considera a afetividade como sensibilidade das relações de força, na qual a vida não deve, mas tão somente devém. Uma Psicologia para (re)ligar a vida às suas forças criativas.

\section{Nota}

${ }^{1}$ Sabemos bem que esta obra, A Vontade de Poder, foi bastante deformada pela má-fé nazista quando da compilação dos textos pela irmã de Nietzsche, Elizabeth Förster-Nietzsche. Contudo, a versão que utilizamos aqui se mostra bastante confiável, por ser bastante recente e partir das intervenções feitas por Peter Gast, amigo íntimo e leal de Nietzsche, tal como esclarece a tradutora logo no início do livro. 


\section{REFERÊNCIAS}

BARRENECHEA, M. A. O Aristocrata Nietzschiano: para além da dicotomia civilização/barbárie. In: LINS, D.; PELBART, P. P. (Org.). Nietzsche e Deleuze: bárbaros civilizados São Paulo: Annablume, 2004.

DELEUZE, G. Nietzsche, Lisboa: Edições 70, 1981.

DELEUZE, G. Crítica e Clínica. São Paulo: Editora 34, 1997.

DELEUZE, G. Nietzsche e a Filosofia. Porto: Rés, 2001.

DELEUZE, G. Espinosa: filosofia prática. São Paulo: Escuta, 2002.

DELEUZE, G. A Ilha Deserta. São Paulo: Iluminuras, 2006a.

DELEUZE, G. Diferença e Repetição. Rio de Janeiro: Graal, 2006b.

DELEUZE, G. L'Abécédaire de Gilles Deleuze. Paris: Montparnasse, 1994. Disponível em: <http://www.dossie deleuze.blogger.com.br/>. Acesso em: 31 jul. 2012.

GIACOIA Jr., O. Nietzsche como psicólogo. São Leopoldo: Unisinos, 2001.

MACHADO, R. Deleuze: a arte e a filosofia. Rio de Janeiro: J. Zahar, 2009.

NAFFAH NETO, A. Psicoterapia em busca de Dionísio: Nietzsche visita Freud. São Paulo: Escuta, 1994.

NIETZSCHE, F. Além do Bem e do Mal: prelúdio a uma filosofia do futuro. São Paulo: Companhia das Letras, 1992.

NIETZSCHE, F. Humano, demasiado humano. São Paulo: Companhia das Letras, 2005.

NIETZSCHE, F. Crepúsculo dos Ídolos. São Paulo: Companhia das Letras, 2006.

NIETZSCHE, F. A Vontade de Poder. Rio de Janeiro: Contraponto, 2008a.

NIETZSCHE, F. Ecce Homo. São Paulo: Companhia das Letras, 2008 b.

NIETZSCHE, F. Genealogia da Moral: uma polêmica. São Paulo: Companhia das Letras, 2009. 
SIMÕES, A. et al. A subjetividade fora da mente. Fractal: Revista de Psicologia, Niterói, v. 23, n. 2, p. 353-366, maio/ago. 2011.

VIANNA, G. M. M. V. Psicologia/arte no pensamento filosófico de Nietzsche. Psicologia: Ciência e Profissão, Brasília, v. 15, n. 1-3, p. 30-31, 1995.

TREVISAN, J. F. Nietzsche e o ressentimento: um estudo em Psicologia Social. 2005. Dissertação (Mestrado)-Programa de Pós-Graduação em Psicologia Social e Institucional, Universidade Federal do Rio Grande do Sul, Porto Alegre, 2005.

Recebido em: 13 de setembro de 2012 Aceito em: 12 de novembro de 2014 